\title{
The Moral Police
}

\author{
Agenda-setting and Framing Effects \\ of a New(s) Concept of Immigration
}

\author{
Tine Ustad Figenschou, Audun Beyer \\ \& Kjersti Thorbjørnsrud
}

\begin{abstract}
How does the general public understand media coverage of immigration issues? The present article analyses the media effects of an extensive news series focusing on the harassment of people believed to disrespect traditional Muslim norms. Through an explorative survey study, it traces how Norwegian media launched and covered what was labeled "the moral police" phenomenon, and to what extent the media framing of the issue had an agendasetting and/or frame-setting effect on the public. It finds that, although most respondents had become aware of the issue through the media, they did not necessarily adopt the media's framing of the phenomenon. The respondents did not primarily relate the "moral police" to immigration (the dominant media frame), they understood the new phenomenon through experiences from their own lives and framed it as a general social problem.
\end{abstract}

Keywords: immigration, public opinion, framing, agenda-setting, media influence

\section{Introduction}

The mediated debate on migration and ethnic minorities is intense, polarized, and emotional (e.g., Cottle, 2000), but to what extent do the media influence public perception of these issues? The present study explores the media effects of a news series concerning majority and minority conflicts and the illegitimate sanctioning of Muslim norms in public space. Using an explorative design, the study traces how the media launched and reframed a new concept, labeled "the moral police", and how the framing of this concept took hold in public opinion.

The story was launched with the following headline - "Grønland [inner-city borough in Oslo] more Islamic than Morocco" - on the front page of the largest Norwegian broadsheet newspaper Aftenposten ${ }^{1}$. The article told a story about the situation in this inner-city borough, known for its multi-ethnic character, vibrant nightlife and creative inhabitants. It documented the illegitimate sanctioning of women not dressed according to traditional Muslim codes; attacks on homosexuals who displayed affection in the streets; and offensive and contemptuous behaviour in bars and cafes towards men who were said to disrespect the codes of Ramadan. In the following months, the phenomenon was covered in great detail and, although national print media led the story, it also spread to the main television and online news outlets. 
The moral police story represents a unique chance to examine agenda-setting and framing effects in natural, real-life settings: It was a new concept introduced by the news media; the media covered the story intensely for a relatively short period of time; and further, although the media coverage started out as a traditional 'Muslim threat' story, the debate quickly diversified as news sources of ethnic minority background succeeded in nuancing and confronting the initial understanding. Aiming to meet the strong call for more framing-effect studies in real-life competitive public debates (see among others Chong \& Druckman 2007a and b; Kinder 2007; Matthes 2008; Slothuus 2010), the analysis offers rich empirical data and new insight into how competing, reallife news frames are established, understood and adopted in public opinion. The article extends the literature on framing by analysing the frame-setting processes that occur in the interaction between media frames and public opinion, through a survey study that examines (1) the public's awareness of a new concept launched in the media (agenda setting), and (2) how the survey respondents frame the phenomenon in their own words when responding to an open-ended question (framing effects).

The present article is structured as follows: The study is first situated in relation to the extant research on immigration coverage, agenda-setting, priming, and framing effects. Next, the methodological approach is detailed. We then describe the media coverage of the "moral police" story and outline how the concept was constructed through three different frames in the media. The analysis of the news media's agenda-setting effect and the framing effects of the "moral police" story follows suit. The main findings from the survey study are finally discussed in the concluding section.

\section{Reception of a Real-life Mediated Immigration Debate}

The media take centre stage in the presentation of migration and ethnic minorities, and a substantial number of text- and content-based studies from various countries have demonstrated that mainstream media tend to construct our image of minorities along the same lines, using similar frames (see among others Cottle 2000, Horsti 2008 and Threadgold 2009 for informative literature reviews). In polarized black or white news stories, they tend to be defined as intruders (queue jumpers, threats or frauds) (Benson 2009, 2010; Cottle 2000; van Dijk 1993; Hafez 2000; Horsti 2010, 2013), but also as heroic victims of war, natural disasters and oppression (van Gorp 2005; Gross \& Threadgold 2007; Horsti 2010, 2013).

The present article takes the debate a step further and asks if and how the immigration debate in the media is picked up by public opinion through an analysis of the agenda-setting and frame-setting potential of the news media. From previous studies within agenda-setting, priming, and framing, we know that the media have the ability to make both issues and frames more salient in the public opinion (Brewer \& Gross 2005; Chong \& Druckman 2007a and b; Fan 1996; Iyengar \& Simon 1993; de Vreese 2004). The mechanisms behind these effects may be different (agenda-setting lingering on $a c$ cessibility, while framing effects may be best thought of as an applicability effect (see Scheufele \&Tewksbury 2007: 14-16)). However, there is probably good reason to also view them as intertwined. In addition, how an issue frame evolves over time, in some instances transforming the public's basic understanding of what is at stake, continues to be poorly understood (Chong \& Druckman, 2007b: 118). Experimental research stud- 
ies suggest that public opinion on immigration and perspectives on race and ethnicity depend systematically on how the issues are framed in the media, for instance, when media reports relate ethnicity to crime or fundamentalism (Domke, McCoy \& Torres, 1999; Entman 1992; Hurwitz \& Peffley 1997; Peffley, Hurwitz \& Sniderman,. 1996; Sniderman \& Piazza 1993). Such experimental studies, while high in internal validity, have been criticized for exposing participants to frames that are very different from how mediated political debates take place in real life (Kinder 2007: 158; Scheufele \& Tewksbury 2007: 18; Slothuus 2010). Because most of these experimental studies expose respondents to constructed, single news items, and test the effects of this exposure immediately, they cannot account for the effects of real-life actual media frames as they occur and evolve over time, often involving complex meanings, contesting perspectives, and multiple stakeholders. Moreover, because experiments are usually conducted in such a way that all participants are exposed to the framing message, whereas in real life different audience groups receive and pay varying amounts of attention to the total number of available frames, experimental studies may exaggerate the power of framing (Kinder 2007: 157; Matthes 2008: 121).

Studies of how actual mainstream news media frame ethnic minorities, on the other hand, are primarily concerned with the inherent message of media texts through different types of textual and content analysis. These studies assume, rather than test, the effects of the frames, representations, constructions, or discourses. Although both media-effects studies and content and textual analysis have examined news on migration, there is a striking lack of research on how the audience interprets and understands real-life news on ethnic minorities and immigration. A notable exception is the large-scale content analysis by Boomgaarden and Vliegenthart (2007), who find that the more the news media reported about immigration-related topics, the higher the aggregate share of vote intention for anti-immigrant parties: an effect that has also been corroborated by experimental evidence (see Beyer, Knutsen \& Rasch 2014).

It is assumed that the frame-setting potential of a message increases when it is repeated frequently, comes from a credible source, and resonates with consensus values and prior beliefs (Chong \& Druckman 2007a). It is further demonstrated that frames relying on affective cues, in other words frames that activate feelings, are more effective than frames relying on cognitive cues (Marcus 2000). Studies of political communication have emphasized particularly the identification of threat and the activation of feelings of fear as crucial to boosting the persuasiveness of a message (ibid.). The media's focus on culture as the foundation of identities and carrier of difference, neglecting structural socio-economic inequalities, has been called a new type of racism, decoded into "acceptable" ideas about cultural and ethnic differences (van Dijk 2000). This emphasis on culture, paired with an increased focus on religion and religious extremism, is particularly salient in the coverage of minorities of a Muslim faith, portraying Islam in opposition to liberal principles and individual freedom and as posing a threat to Western democracies (Altheide 2007; Ehrkamp 2010; Saeed 2007). Based on the assumptions that the type of coverage that plays with such deep-seated fears will be most powerful, we would expect the stereotypical frames of Islam and Muslims to have the greatest impact on public opinion. Accordingly, we expect that more abstract and complex descriptions of the phenomenon would have less impact on public opinion, activating emotions, cognitive processes and, to a lesser extent, evalu- 
ations. An alternative expectation will build on the assumption that multi-perspectival news enhances the likelihood of nuanced public debates and informed public opinion (Chong \& Druckman 2007c).

\section{Method and Design}

\section{Survey}

The survey study was conducted as a web survey three weeks after the initial article introduced the term "the moral police" (Aftenposten, 9 January 2010). Norstat, a Nordic market research company, conducted the survey. Respondents were drawn from their online panel, and 1,000 respondents answered the survey. Respondents were recruited through quota sampling and are representative of the Norwegian Internet population (those with Internet access; panel members are not recruited through Internet use, but through other channels). There is slight over-representation of younger respondents, as can be expected from a web survey; we know that older age groups have a lower tendency to both use and have Internet access. The Internet access data for Norway shows that 91 per cent had Internet access in 2009, higher for men than for women. Internet access increases with education. Our survey may have a slight overrepresentation of younger, more highly educated respondents. When it comes to geographical distribution, we see several minor differences on the county level, but smaller differences when it comes to larger parts of the country. For analyses concerning the co-variation between variables, we find that the sample is sufficient to allow us to make generalizations.

\section{Survey Measures}

Apart from ordinary structural variables such as income, gender, education, and age, we asked people about voting intentions, their general attitudes toward immigration, and their media use. As the main content and debate on the issue was for the most part found in the mainstream national newspapers, it was fruitful to ask specifically for the respondents' use of this medium. We also constructed a media-use index based on all media usage (national and regional newspapers, both online and in print, as well as news consumption via television), and will discuss how these measures were used in the analyses in the regression model reported in the results section.

To capture the nuances of public understanding, we measured how survey respondents voiced different frame elements in their definitions of what constituted the "moral police." Frame elements are defined in line with Entman's (1993) authoritative definition, where the frame elements that together constitute a frame are: a problem definition, a causal attribution, a moral evaluation, and possible recommendations for treatment (Entman 1993: 52; Matthes \& Kohring 2008: 264). How the competing media frames on the moral police phenomenon were picked up by public opinion is measured through closed items that examined the respondents' understanding of the moral evaluations and treatment responsibility concerning the moral police (see Figures 2 and 3). In addition, the respondents' definitions of the concept were measured through an open-ended question, asking respondents to give an account, in their own words, of how they understood the term "moral police". In contrast to closed items, which would be able to measure public opinion on aspects defined beforehand, the open-ended questions aim 
to explore which aspects of the phenomenon the public found particularly salient. The responses to the open-ended question were recoded into the variables stated in Figure 1, aiming to examine how the three above-mentioned media frames were reflected in the respondents' definition of the phenomenon. A team of two coders conducted the analysis and a second coder recoded 10 per cent of the responses. Reliability was assessed by calculating Cohen's kappa, which was found to be satisfactory for all variables, with scores between 0.76 and 0.89 .

\section{Analysis}

\section{The "Moral Police" Story: Source Diversity and Competing Frames}

At first glance, what came to be known as "the moral police story" reflects a tendency in Western mainstream media to reduce conflicts related to immigration and integration to Islamic and cultural practices. As the moral police story developed, however, a complexity of competing frame elements and voices challenged the conventional "Us" and "Them" dichotomy and the news media constructed a "variety of others" (Eide 2011).

Three main and diverging frames could be depicted in the coverage of the moral police phenomenon. We cannot conduct a proper content analysis within the limits of the present article, but in the following we will synthesize the main characteristics of the main newspaper and television coverage of the phenomenon, based on a previous content analysis study (see Beyer, Thorbjørnsrud \& Figenschou 2010)2.

1) The minority frame emphasizes that the "moral police" phenomenon was first and foremost a problem among the Muslim immigrant population (both as aggressors and victims) and was the most frequently used media frame. Among the news sources addressing the causes of the problem, almost half mentioned Islam as an explanation, along with traditionalist values and male chauvinism within the immigrant population. This frame emphasizes a social pressure that is all-encompassing and repressive for those involved, yet largely invisible to the outsider. In the mainstream national media debate, the phenomenon was identified as acts varying from condescending looks and ill-natured rumours to public corrections, threats, harassment, physical attacks, and violence. The values at stake, declared by the bulk of the sources and constituting the repeated message of the journalists, are those of a multicultural city, including diverse ethnic groups and lifestyles. Overall, the aggressors remain a marginalized, silent out-group, representing values that no source is willing to defend in public. Whereas the in-group (ethnic minority, youth voices) has been expanded to encompass a multi-ethnic cosmopolitan "Us", the out-group is nameless, faceless, and related to practices and roles lacking in any positive quality.

2) The general social control frame qualifies and nuances the first frame by emphasizing that this is an example of general, negative social control mechanisms present in all types of societies, thus transcending culture, religion, and ethnicity. Sources arguing for this definition of the phenomenon drew parallels to the strict social control exercised in traditional, narrow-minded rural communities and in the pious, dogmatic local church communities. Overall, these sources did not deny the current problems among ethnic minority groups. What this frame adds is a qualification of the first frame by shifting focus, and by arguing that the phenomenon should not be regarded as a problem related 
to minorities, or to foreign cultures or religions as such. In the total media coverage, one quarter of all the sources stressed the fact that the moral police issue is primarily an example of a broader problem complex of social control.

3) The media campaign frame inverts the problem by arguing that the description of the moral police as a minority problem was a campaign against the Muslim minority rather than a depiction of a real social problem, thus directly contesting the first frame. Almost one fifth of the total news sources argued that the real problem was not the moral police issue, but rather the mainstream media's bias and campaign journalism against Muslims. These sources pointed to prejudice and discrimination as the key factors behind the focus on the moral police as a problem related to Islam, and called for more media coverage of the majority's harassment and discrimination of minorities who wear garments such as turbans and hijabs. None of them defended the social-control mechanisms described by witnesses and victims; rather, they downplayed the problem and emphasized that any type of harassment or violence was against Muslim codes of conduct, and should therefore not be regarded as a problem related to Islam. Muslim youth or student organizations were the primary representatives of these views.

In the moral police story, more than half of the news sources interviewed had an ethnic minority background. These sources were primarily individuals directly affected by the moral police, as inhabitants of inner-city neighbourhoods, but also sources in positions of authority, such as politicians, religious leaders, cultural personalities, and activists, were also active in the debate. Sources of ethnic minority background were central sources both within the minority frame and the social control frame, and they were totally dominant in the media campaign frame. On the one hand, the large number of minority voices demonstrates greater source diversity, while, on the other, it contributes to presenting the issue as a minority issue. This summary demonstrates how real-life framing of a mediated debate tends to be richer and more complex than the frames employed in controlled experiments. All three frames were present during the intense coverage of the moral police phenomenon, supplementing and contesting each other, although presented with varying strength. In the following sections, we aim to examine how these complex mediated frames are interpreted and understood by the survey respondents.

\section{Agenda-setting - Awareness of the Concept}

The moral police concept was very rarely used in public before the news series was launched in January 2010, and it was not included in any Norwegian dictionaries ${ }^{3}$. In the survey, three weeks later, 71 per cent of the respondents said they were aware of the concept, indicating that the media had been successful in establishing this concept among the main news audience. We do not know how many knew about it beforehand, but based on how they defined the issue (see discussion below), it is quite likely that their knowledge did in fact stem from this specific media coverage. To assess how likely it was that awareness of the concept stemmed from media exposure, we first examined the relationships between all types of media use and awareness of the concept. All mediause variables (both online and print-based national and regional newspapers, as well as television news) showed similar linear relationships with awareness. As expected, the strongest impacts were found with media outlets that covered the concept most 
comprehensively and where the term originated (the national newspapers, particularly in Aftenposten). We constructed an index of media use, which shows that heavy media consumers are clearly more aware of the phenomenon than are those who report using the media more occasionally. For the 5 per cent in the highest score group on the media index, almost 90 per cent were aware of the term (compared to 71 per cent in the average population). As media use is likely to be related to other structural variables, such as age and education, we conducted a logistic regression to control for relevant variables (contact authors for details).

Both the effects on awareness from the general media-use index and the reading of national newspapers proved significant when controlling for these variables, indicating a real media effect on awareness of the concept. We found that both increasing age and education increased the likelihood of awareness of the term, together with the reading of national newspapers. Based on the assumption that strong opinions on immigration would be related to a high interest in news on ethnic minorities and immigration, we investigated how awareness was related to political preferences and attitudes towards immigration. In "the minority frame" outlined in the beginning of the article, the practices of the moral police were perceived as examples of a Muslim threat, potentially activating already-established values and beliefs. We found that strong positive opinions towards immigration were correlated with awareness but, surprisingly, no such effect for strong negative opinions towards immigration was found. In line with this, we found that respondents planning to cast their vote in favour of the Progress Party (the most vocal anti-immigration party) were those least likely to have heard about the term. This is particularly intriguing, taking into consideration that the Progress Party has been campaigning against a (covert) "Islamification" of Norwegian society and has had strong issue-ownership with regard to immigration (Karlsen \& Aardal 2011). The comparatively low awareness among those most critical of immigration and most supportive of the Progress Party may be explained by the media framing of the moral police phenomenon: Even though the minority frame emphasized unwanted practices related to Muslims and ethnic minorities, it does not entail a conventional, polarized "Us" and "Them" dichotomy. Moreover, the journalists who initiated and led the coverage of the moral police did not allow representatives from the Progress Party to participate in the debate, in a conscious attempt to mute the anti-immigrant debaters who are often allowed to define the premises for discussions on migration (personal interview with author, 13 September 2010). The fact that the Progress Party officials did not influence the media debate may have made it less relevant for their voters.

\section{Frame Setting - Minority Issue or General Social Problem?}

In the news media, the greater part of the news sources quoted understood the moral police as an illegitimate sanctioning of Muslim norms in public (the minority frame); said that the immigrant groups themselves should solve the problem; and argued that attitude campaigns and information were the preferred solutions (Beyer et al. 2010). In the following, we will discuss how the survey respondents defined the moral police phenomenon, to what they attributed the causal factors behind the issue, to what degree they though of it as a problem for society (moral evaluation), and which actors they felt should be responsible for doing something about it (treatment responsibility). 


\section{Problem Definition and Causal Attribution}

The definition of the problem was measured through an open-ended question, where respondents were asked to give their interpretation of what the issue was all about. The respondents' answers were categorized depending on whether their problem definition emphasized: (1) that the problem was related to an ethnic minority (in line with the minority frame); (2) that the problem concerned social control in general (in line with the general, social control frame); or (3) that the real problem was that of media campaigns and stereotypical representations of Muslims (in line with the media campaign frame) ${ }^{4}$.

In the open-ended questions, we find two quite distinct groups of respondents: One that highlights aspects of the Muslim minority as the issue, and another that chooses to highlight the general problem aspect of the issue. Interestingly, slightly more people constructed the phenomenon as a general social control issue rather than as a minority problem (see Figure 1). Within this group, many respondents used words and concepts that had appeared in the news on the moral police portraying them as a general phenomenon, such as "bygdedyret" ("the village beast"), "blabbermouths," and the Law of Jante, and words connoting social control in rural and Christian communities in Norway. Within the group that defined the moral police as related to ethnic minorities, many referred to religion ${ }^{5}$. This indicates that, for many respondents, the classification of the moral police as a minority problem overlaps with defining it as a phenomenon related to religion-based sanctions. The third problem definition present in the media, what we label the media bias/campaign definition voiced in the news media primarily by members of Muslim youth and student organizations, was notably absent in the survey. The absence of this problem definition points to the acute underrepresentation of respondents of an ethnic minority background in standard Norwegian opinion surveys, including the present study. Moreover, it was the least frequent of the three main media frames and thus least likely to take hold in public opinion.

\section{Figure 1. Problem Definition}

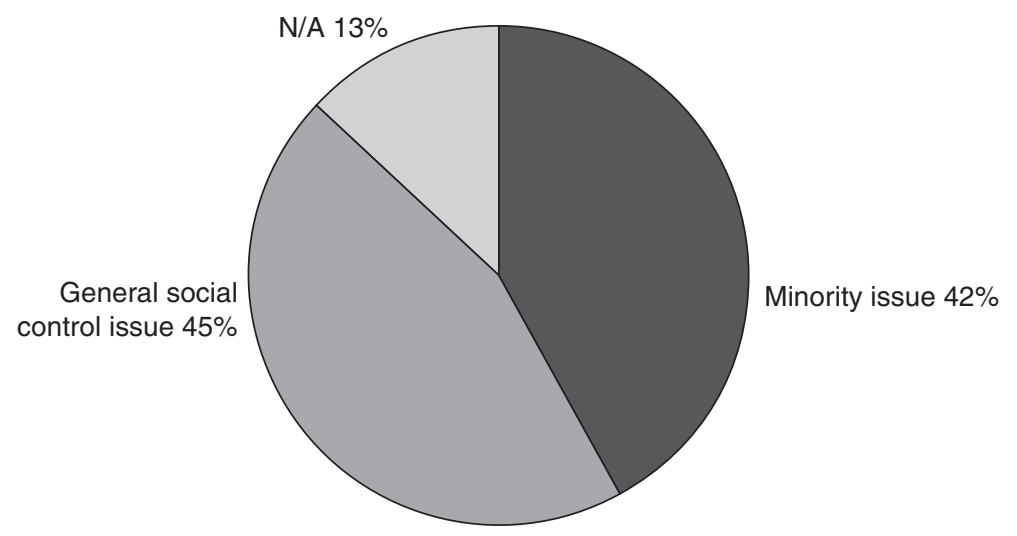

Note: We asked survey respondents to define "the moral police" phenomenon in their own words (open-ended question: "What do you think about when you hear the term 'the moral police'?") Percentages of total respondents who said they were aware of the concept (N: 708). 
Very few of the structural and independent variables were able to explain much of the variation on the problem definition variable, other than that respondents living in Oslo were more likely to view it as a minority problem than were people living elsewhere, and that those most positive toward immigration were more likely to view it as a social control issue. Media use did not seem to have any effect on how the survey respondents defined the moral police, as the news coverage was rich in different definitions and aspects of the problem.

The problem definitions written by the survey respondents in their own words resonate with the complex media frames of the issue, including multiple voices and encompassing several competing frames. On one level, this finding is in line with theoretical assumptions on frame-setting processes (Chong \& Druckman 2007c). On, another, the minority frame, playing with collective threat perceptions and stereotypes, was expected to trump more abstract and general conceptualizations of the phenomenon, particularly because it was the dominant frame in the media coverage. It is thus an interesting finding that the general social control frame, expanding and nuancing the minority frame, was the most salient definition among the public. This finding, demonstrating that the public adopts complex understandings of a controversial phenomenon, could therefore be seen as an argument for deliberation and an informed public discourse.

Another noteworthy characteristic in the open-ended definitions is how rich in connotations and feelings they are. The moral police concept is a term that provides plenty of emotional cues, activating personal experiences, identification, and positioning. Both respondents who emphasized Islam and the immigrant minority and those who underlined the general character of the issue used expressions heavily loaded with negative meaning, such as "moralizing," "hypocritical," "people who think they are better than others," and "people with double standards." The moral police phenomenon thus evoked strong feelings within the public, but, rather than solely contributing to polarization or the construction of an unwelcome, threatening non-western "Other," it contributed to a generic criticism of self-appointed authorities in all groups of society.

\section{Moral Evaluation}

Did the survey respondents consider the moral police a serious challenge to society or more of a minor irritation? To measure the moral evaluation of the problem, we asked people to what degree they felt that the moral police represented a problem for Norwegian society (see Figure 2 below). Over three quarters of those aware of the term believed it posed some kind of threat to or problem for society. It is, of course, hard to say exactly what people mean by "problem." Nevertheless, the news media's emphasis on the story, and the notion that we are faced with a real problem that represents a problem for society at large, became established in public opinion.

Positive attitudes towards immigration in general made viewing it as a large problem less likely, while media use did not prove to have any significant effects here either. We should bear in mind that the respondents analysed here are only those who reported having heard about the concept.

There were, however, differences between respondents who construed the issue as a minority issue, and those who pointed to more general social control definitions. As we remember, these two categories were approximately the same size, with the general 
Figure 2. Moral Evaluation

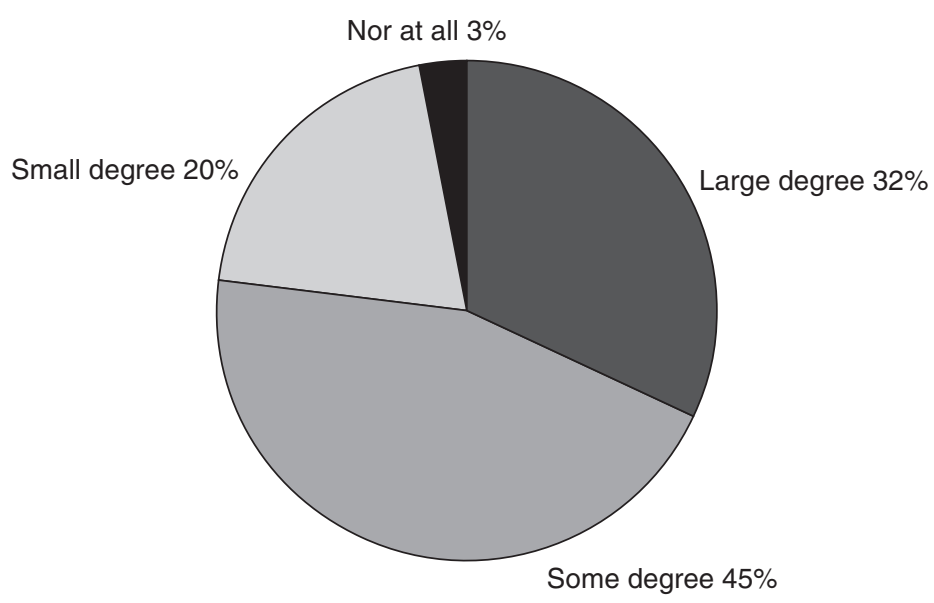

Note: We asked respondents to what degree they felt that the moral police represented a problem for Norwegian society (percentages of total answers) (N: 686).

social control frame being emphasized slightly more. When we analyse the groups with regard to how large a problem they thought it represented, we see a clear pattern, where those who construe the issue as a minority issue seem far more likely to view it as a serious problem for society than do those who interpret it as a general social control issue. At first glance this is a paradox, as one could expect that a general social control issue would mean that more people were affected by the problem. On the other hand, it is only reasonable that the moral police seem more threatening when defined as a problem for the "Other" than when based on the respondents' personal experiences.

\section{Treatment}

For the last of the frame elements, pertaining to any possible treatment recommendations, we chose to measure what actors were attributed responsibility for dealing with the problem. We listed a number of key institutions and involved groups and asked whether they were responsible for treatment (see Figure 3 below).

\section{Figure 3. Treatment Responsibility}

100

80

60

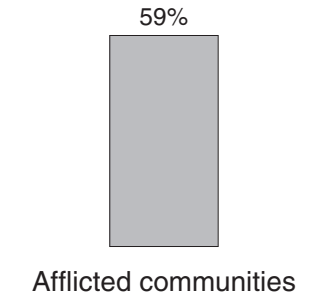

$56 \%$

40

20

0
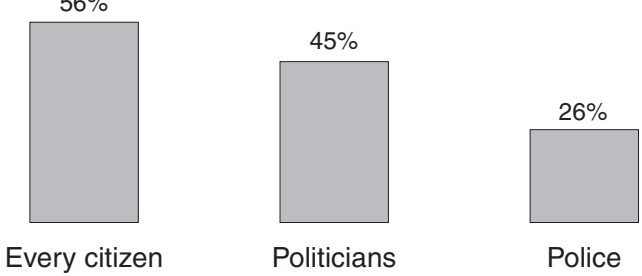

Police

Note: We asked which institutions should assume responsibility for "solving" the moral police phenomenon (multiple choices possible, total adds up to more than 100 percent) (N:686). 
Most of the survey respondents (almost three in five) said that the afflicted groups themselves were responsible for treatment. The high number of respondents calling for the affected groups or communities themselves to take action concurs with the media emphasis on the need for ethnic minority groups to react, and is the only treatment variable that seems to be predicted by media use ${ }^{6}$. Moreover, about half of the respondents saw politicians as partly responsible for doing something about it, although politicians were not emphasized as treatment actors by the media. The attribution of responsibility to politicians suggests that the problem was regarded as being related to policies of immigration and integration or more general social policy, and in some cases as a law and order issue. By naming politicians, one would also signal that not only was the problem caused by failed policies ${ }^{7}$, but also that political action would be able to solve it. As some of the news stories on the moral police featured incidents that could be considered within the realm of the police department's responsibility, we were curious to see how many thought the police could resolve the problem. In fact, more than a quarter meant that the police could play a part in resolving the issue ${ }^{8}$.

A final category in the treatment variable was the one claiming that each one of us, as citizens, has a responsibility to act in opposition to the moral police. Actually, more than half of the respondents thought that each one of us has responsibility for treatment action. This group, as could be expected, was more likely than other groups to view the moral police as a general social problem, while those highlighting the police and politicians as responsible for treatment tended to be more likely to view it as a minority problem. The variable measuring whether or not each one of us has a responsibility correlated negatively with all the other variables. Though fairly low (-.010, -.059, -.136) we believe that this strengthens the argument that the respondents attributing responsibility to each of us construed the problem in a different sense than did the rest of the respondents, namely as a general social problem.

\section{Conclusion}

The present study illuminates how both an issue and a concept introduced by the media have the potential to make people aware of an issue and regard it as important (agendasetting), and how the competing frames are picked up in public opinion (frame-setting). We find a strong awareness within the public of a concept launched in the media, hence we can depict a strong agenda-setting effect in this case. Moreover, public opinion on the phenomenon to a great degree reflects the range of frame elements in the media coverage.

Based on answers to the open-ended survey question, we find that the moral police phenomenon provides plenty of emotional cues, activating personal experiences, identification, and positioning. Overall, the survey definitions concur with Marcus' (2000) argument that messages that rely on affective cues, frames that activate feelings, are more effective than frames that rely on cognitive cues. However, we did not substantiate the assumption that the most classic minority frame, playing on fears of a stereotyped "Other," would supersede more complex alternative frames depicting the moral police as a general phenomenon in public opinion. Rather, we find that multiperspectival news allows room for more complex perceptions than the more pessimistic content analysis and experimental studies would predict. 
In the respondents' own framing of the phenomenon, where more respondents defined the problem as one of general social control than as a minority problem, we find that respondents raised a more generic criticism of self-appointed authorities in all groups of society rather than a strong polarization and construction of an unwelcome, threatening non-Western "Other." These findings raise questions about what makes a frame strong in real-life framing contests. The fact that the most frequent media frame (the minority problem frame) was not the strongest frame in the respondents' understanding of the phenomenon suggests that the respondents' own experiences of social control (the general social control frame) were more important to their understanding of the problem than was frequent media exposure. This is in line with a more complex view of media effects, so-called "negation models" (McQuail 2005 as cited in Scheufele \& Tewksbury 2007: 11), where the media certainly can have "strong attitudinal effects, but that these effects also depend heavily on predispositions, schema, and other characteristics of the audience" (Scheufele \& Tewksbury 2007: 11).

It was also noteworthy that expressions of the media campaign frame (arguing that the moral police story was a campaign against the Muslim minority rather than a depiction of a real social problem) were absent from the survey respondents' own definitions of the phenomenon. The media campaign frame was the least salient of the three main media frames and, thus, the least likely to be reflected in the respondents' understanding of the issue. More importantly, in the news coverage, the media campaign frame was voiced by ethnic minority sources critical of the media's coverage of Islam, and this calls for further investigation of how the authority, credibility, and position of those who voice different understandings and frames influence the public's understanding of the issues. Moreover, those who voiced the media-campaign frame in the media were primarily individuals of ethnic minority background, a group that unfortunately was underrepresented among our survey respondents.

The present research design offers a new and valuable approach to unveiling media influence that has mainly been studied in controlled experiments. Measuring how survey respondents define a phenomenon in their own words using open-ended questions gives rich insight into how a phenomenon is understood within the audience. The design should encourage other researchers to adapt similar strategies in their investigations of the influence of complex media stories and effects. In these studies, the media-use measure employed here should be developed further and tested using refined operationalizations of the respondents' media use.

\section{Notes}

1. “Grønland mer muslimsk enn Marokko," Aftenposten 9 January 2010.

2. We were particularly interested in revealing how different versions of frame elements were voiced, both by sources and journalists in the material. Frame elements were seen as operationalizations of Entman's (1993) four main elements in his definition of framing: A problem definition; a causal attribution; a moral evaluation; and possible recommendations for treatment (see Entman 1993, p. 52; Matthes \& Kohring 2008, p. 264). We propose a view of these elements similar to that of Matthes and Kohring (ibid.), and constructed several variables for each frame element in order to see which aspects were present in the news. The goal was to analyse how the combination of different frame elements can lead to more or less coherent frames - the three main understandings of the "moral police" discussed in the present article. The media outlets analysed were major mainstream national newspapers (Aftenposten, Dagbladet, $V G$ ), and the main news shows as well as political talk shows on the national broadcasters NRK and TV2 from January through March 2010. 
3. From the largest national media database Retriever, we got as few as 190 hits since the archive was established after the Second World War (1945) to January 8th 2010 (the day before the story broke in Aftenposten). Before this date, we identified two main original understandings of the concept prior to the launch of the moral police story: The first and dominant (two thirds of all archived news items) was in foreign reports from states such as Iran, Saudi Arabia, Afghanistan, Palestinian territories, Malaysia, Indonesia, Sudan, Morocco, and Kuwait. In these stories, the term "moral police" referred to physical assaults by police forces and paramilitary groups sanctioning Sharia laws. The second understanding in the archive material (one third of news items) brings the concept into the Norwegian context. Here the concept was used to criticize authorities for expanding their control outside their formal area of authority, or a more basic criticism of censorship and regulation of people's private lives. In January 2010 , by transferring the term to subtle, opaque interpersonal mechanisms of social control in the public space, enacted by individuals at the bottom of the social ladder, the media relate a local phenomenon to an international scene, arguably adding strength to a general psychology of "threat" in the Western world. As the story developed, this threat frame was challenged, modified, and nuanced in a debate that provided the public with a rare media menu of complex new arguments. The moral police case thus arguably qualifies as a "natural experiment," characterized by Kinder (2007: 158) as "a decisive shift in the deployment of frames in some real-world setting taking place in such a way that the putative effects on public opinion - if such effects there be - are fortuitously captured."

4. The category with no relevant responses contains a heterogeneous set of responses, from no answer at all to shorter answers that were impossible to categorize, and responses that were either clearly based on misunderstandings or were nonsensical. As this category was not used for analytical purposes, this should not represent a problem. For the nonsensical remarks, it should be noted that they were few, and that the agency that conducted the survey had, as a quality check, already removed several respondents with incomprehensible answers and respondents who had completed the survey too quickly to be able to read and answer all the questions.

5. The religion variable and the general definition variable were constructed in such a way that the minority aspect and the religious control aspect had the same value, making it possible to perform a correlational analysis. The variables correlated quite strongly, with a Pearson's correlation of .487.

6. We conducted analyses of the statistical relationships between all treatment indicators and relevant background variables. The only significant effect was found for the afflicted communities, where media use was to some degree positively related to the naming of this treatment.

7. This perspective was articulated mainly in the televised debates on the issue (Beyer et al. 2010)

8. This may come as no surprise when we observe how often incidents concerning harassment and physical attacks and other related actions were mentioned in the news coverage (Beyer et al. 2010). However, very few voices mentioned the police as a possible treatment actor in the content analysis, but this was related to the rather low over-all frequency of treatment recommendations throughout the media material (ibid.)

\section{References}

Altheide, D.L. (2007) “The mass media and terrorism," Discourse \& Communication 1: 287-308.

Benson, R. (2009) "What makes news more multi perspectival? A field analysis," Poetics 37: 402-418.

Benson, R. (2010) "What Makes for a Critical Press? A Case Study of French and U.S. Immigration News Coverage," The International Journal of Press/Politics 15, 3-24.

Beyer, A., K. Thorbjørnsrud and T.U. Figenschou (2010) "The Media Moral Police: A case study of the construction and reception of frames related to ethnic minorities". Paper presented at ECREA 2010: 3rd European Communication Conference, (Hamburg 2010).

Beyer, A., Knutsen, C. H., \& Rasch, B. E. (2014). Election Campaigns, Issue Focus and Voting Intentions: Survey Experiments of Norwegian Voters. Scandinavian Political Studies. doi: 10.1111/1467-9477.12029.

Brewer, P.R., and Gross, K. (2005) "Values, framing, and citizens' thoughts about policy issues: Effects on content and quantity," Political Psychology, 26(6): 929-948.

Boomgaarden, H.G. and Vliegenthart, R (2007) "Explaining the rise of anti-immigrant parties: The role of news media content," Electoral Studies 26: 404-417.

Chong, D. and Druckman, J.N. (2007a) "Framing public opinion in competitive democracies," American Political Science Review 101: 637-655.

Chong, D. and Druckman, J.N. (2007b) "A theory of framing and opinion formation in competitive elite environments," Journal of Communication 57: 99-118.

Chong, D. and Druckman, J. N. (2007c) "Framing Theory," Annual Review of Political Science 10:103-126.

Cottle, S. (2000) "Ethnic Minorities and the Media: Changing Cultural Boundaries," Buckingham: Open University Press.

van Dijk, T.A. (1993) “Elite Discourse and Racism,” Newbury Park: Sage. 
Domke, D., McCoy, K., and Torres, M. (1999) "News media, racial perceptions, and political cognition," Communication Research 26: 570-607.

Ehrkamp, P. (2010) "The Limits of Multicultural Tolerance? Liberal Democracy and Media Portrayals of Muslim Migrant Women in Germany," Space and Polity 14: 13-32.

Eide, E. (2011) "Down There and Up Here: Orientalism and Othering in Feature Stories," New York: Hampton Press.

Entman, R.M. (1993) "Framing: Toward Clarification of a Fractured paradigm," Journal of Communication 43: $51-58$.

Entman, R.M. (1992) "Blacks in the News: Television, Modern Racism and Cultural Change," Journalism Quarterly 69(2): 341-361.

Fan, D.P. (1996) "News media framing sets public opinion that drugs is the country's most important problem," Substance Use \& Misuse, 31(10): 1413-1421.

van Gorp, B. (2005) "Where is the frame? Victims and intruders in the Belgian press coverage of the asylum issue," European Journal of Communication 20(4): 484-507.

Gross, B.K. and Threadgold T. (2007) Broadcast News Coverage of Asylum, April to October 2006: Caught Between Human Rights and Public Safety, Cardiff: Oxfam and Cardiff School of Journalism, Media and Cultural Studies.

Hafez, K. (2000) "Islam and the West in the Mass Media: Fragmented Images in a Globalizing World," Cresskill: Hampton Press.

Horsti, K. (2013) “De-ethnicized victims: Mediatized advocacy for asylum seekers,” Journalism: Theory, Practice \& Criticism, 14(2): 78-95.

Horsti, K. (2010) "Balancing the Frame of Threat - Uninvited migrants in Finnish news," in Orgeret, K.S. and A.H. Simonsen (eds.) Elisabeth Eide - det utålmodige mennesket, Oslo: Unipub.

Horsti, K (2008) "Overview of Nordic Media research on Immigration and Ethnic Relations: From Text analysis to the Study of Production, Use and Reception," Nordicom Review 29(2): 275-293.

Hurwitz, J. and Peffley, M. (1997) "Public perceptions of race and crime: The role of racial stereotypes," American Journal of Political Science 41: 375-401.

Iyengar, S. and Simon, A. (1993) News Coverage of the Gulf Crisis and Public Opinion - A Study of AgendaSetting, priming and Framing," Communication Research 20(3): 365-383.

Karlsen, R. and Aardal, B. (2011) "Kamp om dagsorden og sakseierskap,” in Aardal, B. (ed.) Det politiske landskap, Oslo: Cappelen Damm Akademisk.

Kinder, D.R. (2007) “Curmudgeonly Advice,” Journal of Communication 57:155-162.

Marcus, G.E. (2000) “Emotions in Politics,” Annual Review of Political Science 3:221-250.

Matthes, J. (2008) "Media Frames and political judgments. Exploring the boundaries of framing effects in a two-wave panel study," Studies in Communication Science 8: 101-128.

Matthes, J. and Koering, M. (2008) "The Content Analysis of Media Frames: Toward Improving Reliability and Validity," Journal of Communication 58: 258-279.

Peffley, M., Hurwitz, J. and Sniderman, P.M. (1997) "Views of Blacks in the Context of Welfare and Crime Racial Stereotypes and Whites' Political," American Journal of Political Science 41: 30-60.

Saeed, A. (2007) "Media, Racism and Islamophobia: The Representation of Islam and Muslims in the Media," Sociology Compass 1:443-462.

Scheufele, D.A. and Tewksbury, D. (2007) "Framing, Agenda Setting, and Priming: The Evolution of Three Media Effects Models," Journal of Communication 57: 9-20.

Slothuus, R. (2010) "When Can Political Parties Lead Public Opinion? Evidence from a natural Experiment," Political Communication 27:158-177.

Sniderman, P.M., and Piazza, T. (1993) The Scar of Race, Cambridge, MA: Harvard University Press.

Threadgold, T. (2009) The Media and Migration in the United Kingdom, 1999 to 2009. Washington, DC: Migration Policy Institute.

de Vreese, C.H. (2004) “The Effects of Frames in Political Television News on Issue Interpretation and frame salience," Journalism \& Mass Communication Quarterly, 81: 36-52.

Tine Ustad Figenschou, Ph.D., Postdoctoral Fellow, Department of Media and Communication, University of Oslo, tineuf@media.uio.no

Audun Beyer, Ph.D., Postdoctoral Fellow, Department of Media and Communication, University of Oslo, audun.beyer@media.uio.no

Kjersti Thorbjørnsrud, Ph.D., Project Leader 'Mediation of Migration', Department of Media and Communication, University of Oslo, kjersti.thorbjornsrud@media.uio.no 